\title{
Service Learning in Teachers and Students Mentoring for 2020 Bebras Challenge in Pandemic Era at Maranatha Christian University Bebras Bureau
}

\author{
Mewati Ayub ${ }^{1 *}$ \\ ${ }^{1}$ Department of Master of Computer Science, Faculty of Information Technology \\ Universitas Kristen Maranatha, Bandung, Indonesia \\ mewati.ayub@it.maranatha.edu \\ Maresha Caroline Wijanto ${ }^{2}$, Adelia ${ }^{3}$, Billy Susanto Panca ${ }^{4}$, Doro Edi ${ }^{5}$, Julianti Kasih ${ }^{6}$, Hapnes Toba ${ }^{7}$, \\ Risal $^{8}$, Meliana Christianti ${ }^{9}$, Robby Tan ${ }^{10}$, Daniel Jahja Surjawan ${ }^{11}$ \\ 2,4,6,8,9,10,11 Department of Informatics Engineering, Faculty of Information Technology \\ Universitas Kristen Maranatha, Bandung, Indonesia \\ 3,5 Department of Information System, Faculty of Information Technology \\ Universitas Kristen Maranatha, Bandung, Indonesia \\ ${ }^{7}$ Department of Master of Computer Science, Faculty of Information Technology \\ Universitas Kristen Maranatha, Bandung, Indonesia \\ maresha.cw@it.maranatha.edu, adelia@it.maranatha.edu,billy.sp@it.maranatha.edu, \\ doro.edi@it.maranatha.edu,julianti.kasih@it.maranatha.edu,hapnestoba@it.maranatha.edu, \\ laurentius.risal@it.maranatha.edu,meliana.christianti@it.maranatha.edu, \\ robby.tan@it.maranatha.edu,daniel.js@it.maranatha.edu
}

(Received July 10, 2021, accepted August 27, 2021)

\begin{abstract}
Bebras Challenge is a competition for elementary to high school students to educate informatics and computational thinking, followed by sixty countries all over the world. Bebras Indonesia Community in coordination with the International Bebras Committee holds the challenge yearly. Indonesia has participated in the Bebras Challenge since 2016. Faculty of Information Technology Maranatha Christian University as a Bebras Bureau has also been involved in the challenge since 2016. To prepare students for Bebras Challenge, Maranatha Bebras Bureau holds a teacher workshop yearly. The Teacher Workshop supports teachers to strengthen students in practicing Bebras tasks. Data on students who participated in the Bebras Challenge at Maranatha Bebras Bureau indicates increasing numbers from 2016 until 2020. This paper describes a service learning for mentoring teachers and students in the Bebras Challenge, which was held in the pandemic year 2020. Teacher mentoring was using a service learning approach, where the lecturers provided training to the teachers and then the teachers would share their knowledge back to their students. There were advantages and disadvantages of the execution during the pandemic. Although in a distance learning condition, teachers and students were still enthusiastic to participate in Bebras Challenge. The number of students who followed the 2020 Bebras Challenge nearly five times compared to 2019 in the Maranatha Bebras Bureau. The scores of elementary school students who followed the challenge showed very good results. On the
\end{abstract}


other side, the results of junior and senior high school students were not as good as the scores of elementary school students.

Keywords: Bebras Challenge; Bebras Tasks; competition; computational thinking; pandemic

\section{Introduction}

Bebras Indonesia Community founded in 2016 under Tim Olimpiade Komputer Indonesia (TOKI) organization (TOKI, Bebras Indonesia, 2016). The aim of Bebras Indonesia is to introduce informatics and Computational Thinking (CT) to teachers and students in elementary school until senior high school. Bebras Indonesia was accepted as a National Bebras Organizer (NBO) by the Bebras Community in 2017. The duties of an NBO is to organize the national Bebras Challenge annually in its country and contribute to the international Bebras' task workshop. The International Bebras Community is a nonprofit organization. Learning model in Bebras' task is emphasized on the introduction of informatics (computer science) concepts and developing CT in problem solving (Dagienè $\&$ Sentence, 2016).

Computational thinking is a thought process to solve a problem (Aho, 2012) (BBC, 2019). To solve a problem, we should understand the problem, then develop some solutions for the problem. The solution can be represented as algorithm steps. CT should be owned by every child so they have the ability to solve problems and critical thinking to face the challenge in the digital era. Valentina in (Mannila, et al., 2014) mentioned that some countries in Europe and the United States have implemented CT in the curriculum for K-9. The aim of CT introduction from an early age is to develop problem solving ability from elementary school, so at senior high school they will have a deeper understanding of CT. The World Economic Forum also states that five skills needed to face competition in working in 2025 are analytical thinking \& innovation, active learning, and learning strategies, complex problem solving, critical thinking and analysis, creativity, originality and initiative (Whiting, 2021). Problem solving and critical thinking are in third and fourth order, the abilities are very important. Using Computational Thinking, teachers and students are able to utilize digital tools smartly in solving problems in daily life. Besides that, the Indonesian PISA test is still below world ranking in 2015, for science, mathematics, and reading (OECD, 2016). Introducing CT in Indonesia from an early age is expected to be able to speed up Indonesian PISA test. 
To reach teachers and students in all areas in Indonesia, Bebras Indonesia has collaborated with universities and colleges, especially those which have informatics study programs. A university or college that becomes a partner of Bebras Indonesia is called Bebras Bureau. Until now, there are 87 Bebras Bureau in Indonesia (TOKI, Bebras Biro, 2021). Maranatha Bebras Bureau Christian University, next will be referred to as the Maranatha Bebras Bureau, has joined with Bebras Indonesia since 2016. The implementation and evaluation of Bebras Challenge in Maranatha Bebras Bureau in 2016, 2017, and 2018 have been discussed in (Ayub, et al., 2017) (Wijanto, et al., 2019). This paper describes service learning of the Maranatha Bebras Bureau for teachers workshop to prepare students in the 2020 Bebras Challenge.

\section{Method}

The method used in the teachers' mentoring is service learning (Ansori, Afandi, Fitriyah, Safriyani, \& Farisia, 2021). Service learning is a strategy of teaching and learning, which combines learning in class with the needs and problems in the society. In these activities, the aim of service and learning has the same weight, which is mutually enriched. Teachers workshop and mentoring carried out by lecturers and university students are expected to add new knowledge for teachers and later on, teachers can also share it back with their respective students.

To prepare teachers and students in the Bebras Challenge (BC), Bebras Indonesia has a standard procedure. Teachers are suggested to follow a Computational Thinking and Bebras Challenge workshop, which is held by Bebras Bureau. Facilitators who presented the subjects in the workshop are lecturers that have joined the national workshop from Bebras Indonesia. The mentors of teachers are other lecturers of the faculty.

Teachers deliver CT concept to the students through Bebras tasks. Bebras tasks are presented as a problem description which is complemented with an interesting picture, which supports the students in understanding the problem solving. Each task relates to a concept in informatics and computational thinking (Dagiene \& Stupuriene, 2016) (Dagienè \& Sentence, 2016) (Vilnius, Bebras International Challenge on Informatics and Computational Thinking, 2005), but it can be answered without knowing the concept in advance. Bebras tasks are available at several levels, from elementary school, junior high school, and senior high 
school. The International Bebras Community holds a Bebras task workshop annually to collect Bebras tasks from all NBO around the world. Each task will be reviewed tightly to become tasks that will be used in the Bebras Challenge.

A Bebras task consists of a description and an interesting picture as a stimulus, that should be answered in three minutes. The answer can be a multiple choice, a short answer, or interactivity answer using drag and drop. In Indonesia, Bebras tasks are available in discussion books which can be downloaded from the official site of Bebras Indonesia (link https://bebras.or.id/v3/pembahasan-soal/). The tasks can also be accessed online at the link https://latihanbebras.ipb.ac.id/, that is a site to practice Bebras tasks at IPB server. The Bebras task example is shown in Figure 1. The lecturers should be ready to discuss with the teachers, if there are tasks which need some explanations of the solutions.

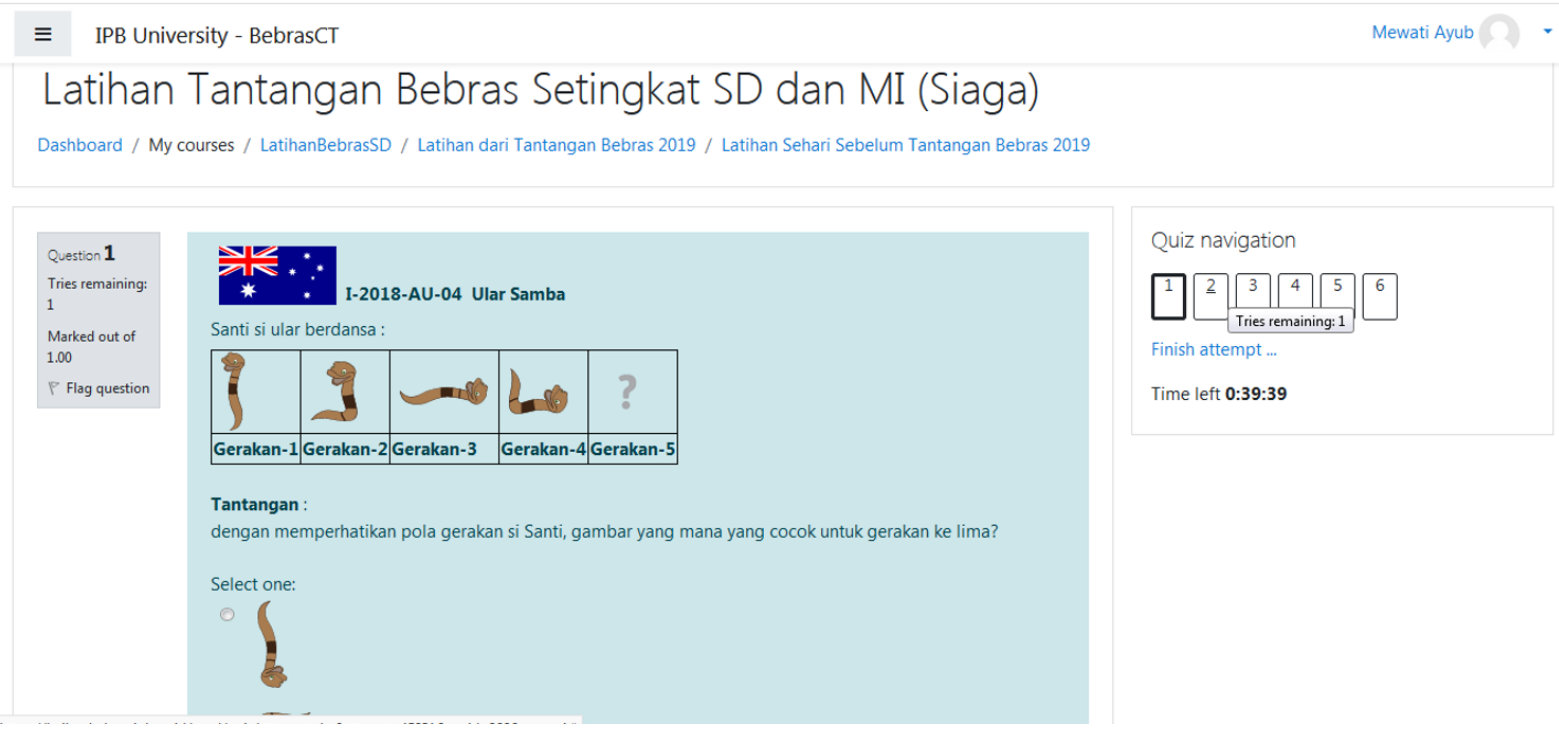

Fig. 1. Bebras task example accessed through site of IPB.

Bebras Challenge is performed annually in the second week of November. The schedule will be fixed by Bebras Indonesia at the National Workshop in coordination with all Bebras Bureau. Because of online implementation, Bebras Bureau will provide the computer laboratory in their university to accommodate the participants. If a school has an adequate computer laboratory, the challenge can be held in its laboratory with a supervisor from Bebras Bureau. From 2016 to 2019, the Bebras Challenge was held in all areas of Indonesia using the explained procedure. 
Pandemic of COVID-19 in the 2020 caused teacher workshop, preparation and implementation of BC can not be performed on site in Bebras Bureau or in school as previous years. The Maranatha Bebras Bureau has prepared a scenario for teachers and students mentoring at pandemic year 2020. Figure 2 shows an approach to prepare and implement the 2020 Bebras Challenge in Maranatha Bebras Bureau.

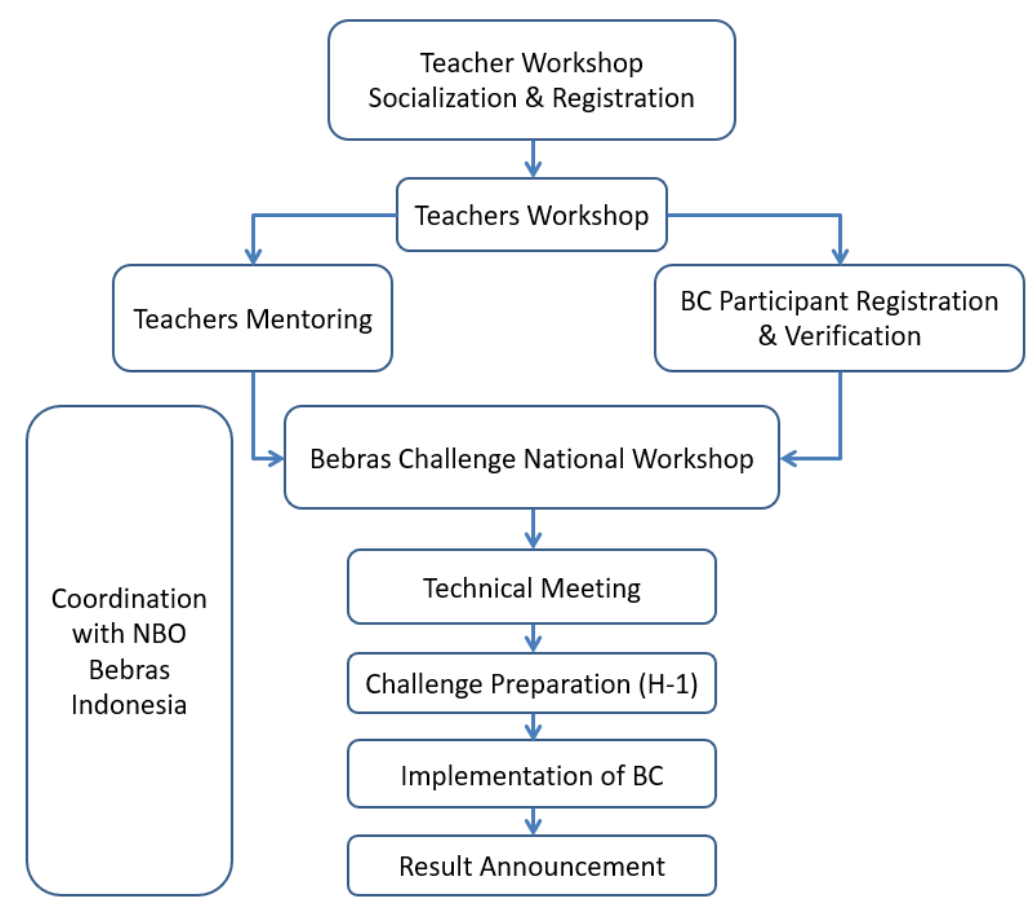

Fig. 2. Scenario of preparation and implementation of Bebras Challenge

For the teacher workshop, promotion of the workshop in the schools was performed by distributing proposals through email and WhatsApp groups. The teacher workshop was conducted on 12 September and 18 September 2020 online via Zoom meeting to introduce computational thinking and Bebras tasks. Fig. 3 shows a picture of the online teacher workshop. After the workshop, the teachers were mentored by lecturers to deliver computational thinking and Bebras tasks to the students.

The exercise of Bebras tasks was begun in online discussion with the students. Bebras task can be taken from the discussion book or the site of IPB. Teachers can consult with the lecturers to discuss the Bebras tasks. The teachers were suggested to explore the Bebras task, not just focused on the right answer. The students should understand how to solve the problem behind the task. The teachers were also suggested to have an account on an IPB site to know the online interaction, before they guided their students. 


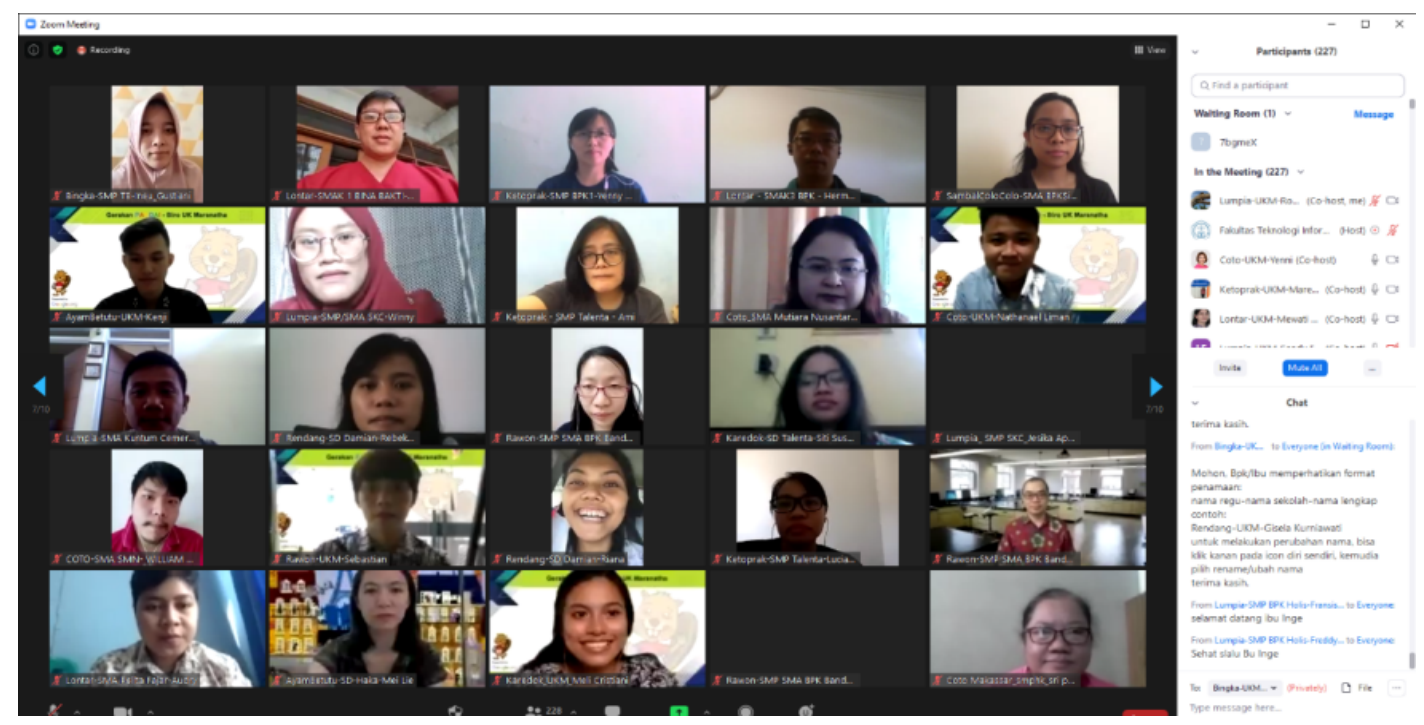

Fig. 3. The implementation of online teachers workshop

The 2020 Bebras Challenge's schedules and rules were fixed at an online national workshop by Bebras Indonesia on 10 October 2020 by inviting all Bebras Bureau in Indonesia. Schedules of the 2020 Bebras Challenge were on 10 November 2020 for senior high school, 11 November 2020 for junior high school, and 12 November 2020 for elementary school.

Teachers registered students to follow the Bebras Challenge through a data file in Excel format, sent by e-mail to the Bebras Bureau. Teachers were assisted in registering their students, that is, ensuring data was filled in with complete students' attributes, such as student name, gender, email, school name, and school level. Bebras Bureau would check the completeness and the accuracy of the data. The teachers were suggested to register the students at the IPB site, so the students can practice online to solve the tasks.

Coordination with teachers for Bebras Challenge preparation was performed at a technical meeting via a Zoom meeting on 30 October 2020. In the meeting, Bebras Bureau presented the schedules, the procedures and the rules of Bebras Challenge, also the deadline of participants register, correction of participant data, and login account for the challenge. The special guide was provided for parents of elementary school students, because they performed the challenge online from their home and still needed assistance from parents.

A week before the Bebras Challenge, participants' data was uploaded to the IPB site by the Bebras Bureau. After the data upload succeeded, Bebras Bureau downloaded participants' accounts for the challenge, and then distributed the accounts to teachers of each school. 
As the standard procedure of Bebras Challenge, one day before the challenge, each participant should practice in the Bebras Challenge site (https://tantanganbebras.ipb.ac.id/), to ensure the account can be used and to familiarize with the challenge procedure. To support teachers and students mentoring, Bebras Indonesia issued a guideline of Bebras Challenge, a guideline of elementary school counterpart. Bebras Bureau completed the guidelines with steps for creating an account on IPB site, also steps for practising in IPB site.

The number of school participants of the 2020 Bebras Challenge in Maranatha Bebras Bureau were 40 schools. To optimize teacher mentoring, two lecturers and one university student mentored teachers from two or three schools. The mentors guided teachers in explanation of Bebras task solution, registering participant data, and guiding at the implementation of online challenge.

\section{Results and Discussions}

\section{Results}

Towards the contest, the mentors reminded the teachers to ensure each participant has practiced and performed pre challenge on $\mathrm{H}-1$ with no obstacles. The mentors were ready to support if there were problems in preparation.

The schedule of 2020 Bebras Challenge can be seen in Table 1. Table 1 also shows the duration and the number of tasks of each school level. The challenge occurred from 08:00 AM to 04:00 PM GMT+7 for all school levels. There are two categories for elementary school, junior elementary school from grade 1 to grade 3, and senior elementary school from the $4^{\text {th }}$ to $6^{\text {th }}$ grade.

Table 1. The schedule of 2020 Bebras Challenge

\begin{tabular}{lccc}
\hline \multicolumn{1}{c}{ Level of school } & Date & $\begin{array}{c}\text { Number of } \\
\text { tasks }\end{array}$ & $\begin{array}{c}\text { Duration } \\
\text { (minutes) }\end{array}$ \\
\hline Junior Elementary School & 12 November 2020 & 8 & 30 \\
Senior Elementary School & 12 November 2020 & 12 & 40 \\
Junior High School & 11 November 2020 & 15 & 45 \\
Senior High School & 10 November 2020 & 15 & 45 \\
\hline
\end{tabular}

To prevent misinformation at the contest, there were intensive communications between the mentors and the teachers or students, between the mentors and the bureau coordinator, and 
also between the bureau coordinator with Bebras Indonesia. All of the communications were done using chats via WhatsApp group, calls or emails.

Because of the pandemic condition, most of the participants performed the online contest from their own home using a smartphone, a tablet or a laptop. Only a few schools performed the challenge in the school laboratory. Fig. 4 and Fig. 5 show the contest participants.

In addition to limitation of telecommunication infrastructures in Indonesia or tools used by the participants, Bebras Indonesia opened exceptions reporting at the time of the contest. The exceptions may be power outages or internet disturbance. In exceptional cases, students or parents (for elementary school) could report to the teacher. The teacher delivered the report to the mentor. The mentor sent the report to the coordinator. The coordinator reported the cases to Bebras Indonesia. The communication was done through chats via WhatsApp group, calls, or emails. The participants, which encountered the exception were recorded. On 13 November 2020, after the challenge was finished, the contest committee evaluated the cases and decided the way out. The committee gave an opportunity to the participants of the cases to redo the contest in certain schedules.

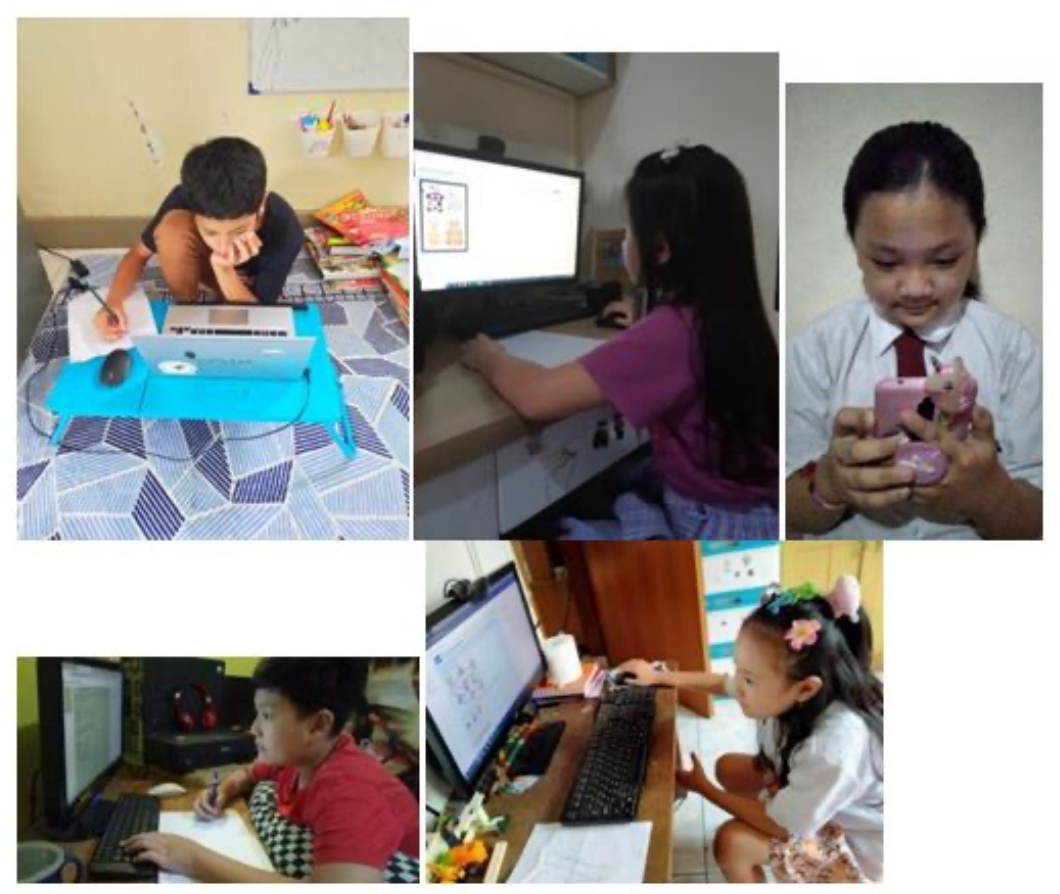

Fig. 4. Online Bebras Challenge for elementary school 

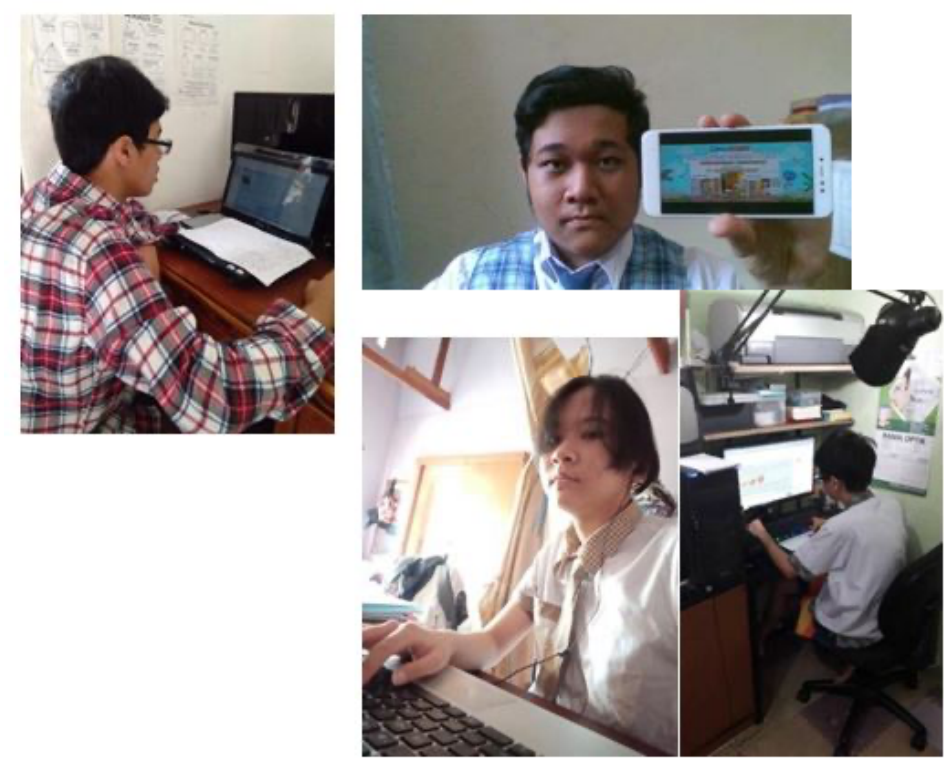

Fig. 5. Online Bebras Challenge for junior and senior high school.

Table 2 shows information about contest participants' distribution in the Maranatha Bebras Bureau. Total participants were 1,740, with 190 students in junior elementary school (11\%), 338 students in senior elementary school (19\%), 918 students in junior high school (53\%), and 294 students in senior high school (17\%). The order from the most to the least number of participants were junior high school, elementary school, and senior high school. Based on gender, male participants were $52 \%$ and female participants were $48 \%$. Elementary school participants were from 24 schools, where 13 schools have followed the Bebras Challenge from the previous year, and 11 new schools. Junior high school participants were from 18 schools, with 3 new schools, while senior high schools from 19 schools with 6 new schools.

The national contest participants in 2020 were 2,543 for junior elementary school, 3,297 for senior elementary school, 5,870 for junior high school, and 4,467 for senior high school. All national participants were 16,177 (TOKI, Pengumuman Hasil Bebras Indonesia Challenge 2020, 2020).

Table 2. Distribution of participants in Maranatha

\begin{tabular}{|c|c|c|c|}
\hline Level of school & Female & Male & Sub total \\
\hline Elementary School(Junior) & 79 & 111 & 190 \\
\hline Elementary School(Senior) & 158 & 180 & 338 \\
\hline Junior High School & 472 & 446 & 918 \\
\hline Senior High School & 131 & 163 & 294 \\
\hline Total & 840 & 900 & 1,740 \\
\hline
\end{tabular}


Table 3 shows statistics for the contest results of elementary school in the Maranatha Bebras Bureau. The average score of junior elementary school was 65.22 , while the average score of senior elementary school was 60.46. There were 29 students in junior elementary school $(15 \%)$ who obtained a full score of 100 , but there were 4 students $(2 \%)$ who obtained a minus score. For senior elementary school, the highest score was 90.28 , but no students obtained a minus score.

For students, who obtained a score greater or equal to 50 , the scores would be stated in the contest certificate. There were $71 \%$ of junior elementary school students and $70 \%$ of senior elementary school students which obtained a score greater or equal to 50. In 2019, the average of elementary schools in Bebras Bureau Maranatha was 48.46, and there were 51\% of elementary schools which obtained a score greater or equal to 50 (TOKI, Pengumuman Hasil Bebras Indonesia Challenge 2019, 2019). The comparison of 2020 to 2019 shows an increase of 12 points in the average and $19 \%$ for participants, which obtained a score greater or equal to 50.

Table 3. Score statistics of elementary school participants

\begin{tabular}{lccccc}
\hline \multicolumn{1}{c}{ Level } & Average & Maximum & Minimum & Score $>=50$ & Score $<50$ \\
\hline $\begin{array}{l}\text { Elementary } \\
\text { School (Junior) }\end{array}$ & 65.22 & 100 & -6.25 & $71 \%$ & $29 \%$ \\
$\begin{array}{l}\text { Elementary } \\
\text { School (Senior) }\end{array}$ & 60.46 & 90.28 & 6.94 & $70 \%$ & $30 \%$ \\
\hline
\end{tabular}

Table 4 shows the statistics for contest results of junior and senior high school in the Maranatha Bebras Bureau. The average score of junior high school was 34.96, while the average score of senior high school was 37.07. There was one student in junior high school who obtained a full score of 100 , but there were 31 students (3\%) who obtained a minus score. For senior high school, the highest score was 86.67 , there were 10 students (3\%) who obtained a minus score. The participants of junior high school who obtained scores greater or equal to 50 were $22 \%$, while the participants of senior high school were $26 \%$.

Table 4. Score statistics of junior and high school participants

\begin{tabular}{lccccc}
\hline \multicolumn{1}{c}{ Level } & Average & Maximum & Minimum & Score $>=50$ & Score $<50$ \\
\hline $\begin{array}{l}\text { Junior High } \\
\begin{array}{l}\text { School } \\
\text { Senior High }\end{array}\end{array}$ & 34.96 & 100 & -13.33 & $22 \%$ & $78 \%$ \\
School & 37.07 & 86.67 & -11.94 & $26 \%$ & $74 \%$ \\
\hline
\end{tabular}




\section{Discussions}

The implementation of the 2020 Bebras Challenge in the pandemic era is a challenge that was not easily carried out by both Bebras Indonesia and Bebras Bureau. The online teacher workshop also limited the communication with teachers and schools. However, this was overcome by having a mentor lecturer who accompanies the teacher. Mentor lecturers were arranged in pairs to assist teachers in conveying Bebras questions to students. Intense communication was built through email, calls, or chat in WhatsApp groups, due to the restrictions on face-to-face meetings.

In the midst of the pandemic difficulties, the interest of schools and students participating in the 2020 Bebras Challenge turned out to increase drastically by $236 \%$ from 6,846 students in 2019 to 16,177 in 2020 (TOKI, Pengumuman Hasil Bebras Indonesia Challenge 2019, 2019) (TOKI, Pengumuman Hasil Bebras Indonesia Challenge 2020, 2020). Bebras Indonesia prepared guidelines not only for teachers or schools, but also for parents, especially for elementary school students' parents. This is because most of the communication between teachers and students in schools was also done online.

There is a considerable difference, when viewed from the achieved average score, between the result in Table 3 and Table 4. The average score for both junior and senior elementary schools is above 50, while the average score for both junior and senior high schools is below 50. Several possible reasons are that the elementary school teachers were more intense in training their students. This is supported by the large number of elementary school teachers who consulted with mentor lecturers about the solution of Bebras tasks. Meanwhile, for junior and senior high schools, students were considered more capable of learning on their own, so the training was not carried out intensely. The other thing is, not all of the students prepared well because they were also adapting to online learning situations.

The difficulty level of Bebras task given to junior and senior high school students actually was higher than the task for elementary school students. From the experience of mentoring teachers and students in the previous challenges, elementary school students generally finished the competition faster than the time allotted, so before the challenge comes to an end, most of them have finished answering all the questions. As for junior high and high school students, they used the time of the competition until the time ends. The limitations of 
devices and computer networks used by students were also obstacle in completing the challenge. There were some students who faced network problems during the competition. However, in the midst of these limitations, there were students who could overcome the challenges of achieving good grades.

\section{Conclusion}

During the pandemic era, the 2020 Bebras Challenge was still successfully carried out on November 10 until 12 2020. The number of participants of 2020 Bebras Challenge also increased significantly, both in Maranatha Bebras Bureau and other bureau. Because of online implementation of the Bebras Challenge, more participants who were initially limited in the distance became willing to get involved. This online implementation also limited the communication between Bebras Bureau and the teachers during the preparation and implementation. However, the intensive teacher mentoring at the Maranatha Bebras Bureau could resolve the obstacles properly. The results of the service learning method show successful implementation in junior elementary school (71\%) and senior elementary school (70\%). Meanwhile, the result of junior high school (22\%) and senior high school (26\%) are not good.

There are some possible reasons. The elementary school teachers are more intensive in training their students, while the junior and senior high school students are considered more capable training by themselves. To push the spirit of the older students to practice, Bebras Bureau can hold a pre challenge before the Bebras Challenge.

In the limitations of this pandemic, the participants of the 2020 Bebras Challenge could still achieve good grades, so more participants were also able to comprehend Computational Thinking. The comprehension of CT would support the students to answer the challenge in the current digital era.

Continuity of teachers mentoring is a very important thing, the teachers can be more confident in sharing Computational Thinking to their students. Therefore, the Bebras Challenge participants can also increase and their achievements will be better. As a continuation of the introduction of CT through the Bebras Challenge, Bebras Indonesia, with support from Google, will organize a Gerakan PANDAI (Pengajar Era Digital Indonesia). 
Gerakan PANDAI is a movement for teachers who have become Bebras partners to be able to implement the concept of $\mathrm{CT}$ in the learning process in their schools, starting from elementary to high school.

\section{Acknowledgements}

Thank you to the Center of Research and Community Service Maranatha Christian University for supporting funds for the implementation of this community service. Thanks also to Bebras Indonesia, especially Dr. Ir. Inggriani Liem as a Chairman of Bebras Indonesia who has provided the opportunity for the Faculty of Information Technology Maranatha Christian University to become one of the Bebras Indonesia Bureau in organizing the 2020 Bebras Challenge.

\section{References}

Aho, A. V. (2012). Computation and Computational Thinking. The Computer Journal, 55(7), 832-835. https://doi.org/10.1093/comjnl/bxs074 CT

Ansori, M., Afandi, A., Fitriyah, R. D., Safriyani, R., \& Farisia, H. (2021). PendekatanPendekatan dalam University Community Engagement. UIN Sunan Ampel Press.

Ayub, M., Wijanto, M. C., Senjaya, W. F., Karnalim, O., Kandaga, T., Witono, T., et al. (2017). Edukasi Berpikir Komputasional melalui Pelatihan Guru dan Tantangan Bebras untuk Siswa di Bandung pada tahun 2016. Sendimas. Bandung.

BBC. (2019). Introduction to Computational Thinking. Retrieved June 2019, from https://www.bbc.com/bitesize/guides/zp92mp3/revision/1

Dagienė, V., \& Sentence, S. (2016). It's Computational Thinking! Bebras Tasks in the Curriculum. In Informatics in Schools: Improvement of Informatics Knowledge and Perception (pp. 28-39). Springer. https://doi.org/10.1007/978-3-319-46747-4_3

Dagiene, V., \& Stupuriene, G. (2016). Bebras - a Sustainable Community Building Model for the Concept Based Learning of Informatics and Computational Thinking. Informatics in Education, 15(1), 25-44. https://doi.org/10.15388/infedu.2016.02

Mannila, L., Dagiene, V., Demo, B., Grgurina, N., Mirolo, C., Rolandsson, L., \& Settle, A. (2014). Computational Thinking in K-9 Education. Proceedings of the Working Group Reports of the 2014 on Innovation \& Technology in Computer Science Education Conference, (pp. 1-29). https://doi.org/10.1145/2713609.2713610 
OECD. (2016). PISA 2015 Results : Executive Summary.

TOKI. (2016). Bebras Indonesia. (Tim Olimpiade Komputer Indonesia) Retrieved August 18,2017 , from bebras.or.id

TOKI. (2019). Pengumuman Hasil Bebras Indonesia Challenge 2019. Retrieved from https://bebras.or.id/v3/pengumuman-hasil-bebras-indonesia-challenge-2019/

TOKI. (2020). Pengumuman Hasil Bebras Indonesia Challenge 2020. Retrieved from https://bebras.or.id/v3/pengumuman-hasil-bebras-indonesia-challenge-2020/

Vilnius, U. o. (2005). Bebras International Challenge on Informatics and Computational Thinking. (Vilnius University) Retrieved August 15, 2017, from bebras.org

Whiting, K. (2021). These are the top 10 job skills of tomorrow - and how long it takes to learn them. Retrieved from Word Economic forum: https://www.weforum.org/agenda/2020/10/top-10-work-skills-of-tomorrow-howlong-it-takes-to-learn-them/

Wijanto, M. C., Ayub, M., Senjaya, W. F., Toba, H., Santosa, S., Karnalim, O., et al. (2019). Evaluasi Pelaksanaan Tantangan Bebras untuk Siswa di Biro Universitas Kristen Maranatha pada tahun 2017 - 2018 untuk Edukasi Computational Thinking. Prosiding Seminar Nasional Hasil Pengabdian Kepada Masyarakat (Sendimas), 4, pp. 295-301. Semarang. 